\title{
Thermal inactivation of Listeria monocytogenes studied by differential scanning calorimetry
}

\author{
Wayne A. Anderson, Nicholas D. Hedges, Martin V. Jones and Martin B. Cole* \\ Unilever Research, Colworth Laboratory, Sharnbrook, Bedford MK44 ILQ, UK
}

(Received 3 September 1990; revised 23 January 1991; accepted 25 February 1991)

\begin{abstract}
The effect of $\mathrm{NaCl}$ on the thermal inactivation of Listeria monocytogenes has been investigated by conventional microbiological techniques and by using differential scanning calorimetry (DSC). Addition of $1.5 \mathrm{M}-\mathrm{NaCl}$ to cells grown at lower $\mathrm{NaCl}$ concentrations significantly increases the tolerance of cells to mild heat stress $\left(56-62{ }^{\circ} \mathrm{C}\right)$. DSC thermograms show five main peaks which are shifted to higher temperatures in the presence of $1.5 \mathrm{M}-\mathrm{NaCl}$. Measurement of loss of viability in the calorimeter gave good correlation between cell death and the first major thermogram peak at two $\mathrm{NaCl}$ concentrations. The time course of the loss of this first peak when cells were heated and held at $60{ }^{\circ} \mathrm{C}$ in the calorimeter matched the loss of viability, whereas the peak attributable to DNA showed little change during this process. The use of DSC to investigate the mechanisms involved in thermal inactivation is discussed.
\end{abstract}

\section{Introduction}

The thermal resistance of the food-borne pathogenic bacterium Listeria monocytogenes has been investigated in a variety of foods and model systems including milk (Bunning et al., 1988), meat and vegetables (Conner $e t$ al., 1986; Gaze et al., 1989), and in relation to microwave-heated foods (Coote et al., 1990). These studies indicate that environmental conditions during heating can have significant effects on thermal inactivation. A number of these conditions have been quantified in other bacteria, for example, the effect of reduced water activity in increasing the heat resistance of Salmonella spp. (McDonough \& Hargrove, 1968; Goepfert et al., 1970; Corry, 1974). In the majority of these studies the underlying molecular mechanisms have not been investigated.

The primary site of damage in the cell may vary with the severity of the stress. Hence, with mild heat, freezing or osmotic shock, membrane damage has been frequently observed and leakage of potassium and other cellular solutes correlates with loss of viability (Lambert \& Hammond, 1976). At high temperatures, denaturation of proteins might be a major factor in cell death. Release of magnesium from the outer membrane of Gramnegative bacteria and from cell-wall teichoic acids of

Abbreviations: DSC, differential scanning calorimetry; TPB, tryptic phosphate broth.
Gram-positive bacteria, damage to ribosomes, and inactivation of specific enzymes or transport systems are other reported consequences of thermal or freeze injury (Hurst, 1984; Ray, 1984, 1986). Ray (1986) has also speculated that some repairable injury may involve conformational changes in macromolecules and that recovery involves reversal rather than de novo synthesis. Such events may be more difficult to investigate experimentally.

Ribosomal damage and degradation have been observed in several Gram-negative bacteria following thermal stress (Lee \& Goepfert, 1975; McCoy \& Ordal, 1979). In Staphylococcus aureus, sub-lethal heating causes both release of wall magnesium and destabilization of the ribosomes (Hurst \& Hughes, 1978, 1981). Hurst (1984) has argued that ribosome damage is a result of magnesium depletion, as heating in a Tris $/ \mathrm{MgCl}_{2}$ buffer does not result in dissociation of the ribosomes into $30 \mathrm{~S}$ and $50 \mathrm{~S}$ particles, whereas heating in a magnesiumchelating buffer does. In both buffer systems membrane damage occurs and increased salt sensitivity of the surviving cells is similar (Hurst \& Hughes, 1978). The primary sites of thermal damage in Gram-positive bacteria and consequences of these on other cellular functions require further study.

The technique of differential scanning calorimetry (DSC) has been used to compare the thermal denaturation curves (thermograms) of bacteria (Verrips \& Kwast, 1977; Miles et al, 1986) and to determine the base 
composition of bacterial DNA (Mackey et al., 1988). The instrument has also been used to accurately apply heat to bacteria and determine thermal death times (Grieme \& Barbano, 1983). However, the two uses of the instrument have not been combined to compare thermograms concurrently with the reduction of bacterial numbers due to heat, nor has the technique been used to define the sequence of denaturation in whole cells that occurs during thermal inactivation of bacteria under different environmental conditions.

In the present study we have investigated the effects of $\mathrm{NaCl}$ on the thermal inactivation of $L$. monocytogenes and, using DSC, have attempted to correlate loss of viability with specific denaturation events within the cell.

\section{Methods}

Organisms and media. Listeria monocytogenes ATCC 19115 and $L$. monocytogenes Scott A were obtained from J. S. Crowther and $\mathbf{H}$. Seliger, respectively. Cultures were grown at $30^{\circ} \mathrm{C}$ overnight in tryptic phosphate broth (TPB) at pH 7.0 (Conner et al., 1986) and maintained on slopes of tryptone soy agar (TSA) (Oxoid) at $4{ }^{\circ} \mathrm{C}$.

Thermal inactivation studies. An overnight culture was resuspended in $10 \mathrm{ml}$ TPB or TPB plus $\mathrm{NaCl}$ at a cell density of approximately $10^{9} \mathrm{ml}^{-1}$. After $15 \mathrm{~min}$ incubation at $20^{\circ} \mathrm{C}$ the suspension was heated in a submerged-coil heating apparatus (Cole and Jones, 1990). Samples $(0.2 \mathrm{ml})$ were removed at predetermined intervals and rapidly cooled in $5 \mathrm{ml} \mathrm{TPB}$. After $90 \mathrm{~min}$ resuscitation, to allow for recovery of heatinjured cells, survivors were counted following serial dilution in TPB and plating on TSA.

Differential scanning calorimetry (DSC). (i) Sample preparation. An overnight culture was centrifuged at $8000 \mathrm{~g}$ for $15 \mathrm{~min}$ and resuspended in $10 \mathrm{ml}$ citrate/phosphate buffer $(100 \mathrm{mM}, \mathrm{pH} 7.0)$ with or without $\mathrm{NaCl}$. After incubation for $15 \mathrm{~min}$ at $20^{\circ} \mathrm{C}$, cells were repelleted and weighed samples (10-13 mg wet wt) were hermetically sealed in $20 \mu \mathrm{l}$ aluminium DSC pans. Reference pans contained $10 \mu \mathrm{l}$ of suspension buffer.

(ii) Calorimetry. Samples were heated in a Perkin Elmer DSC-7 instrument at $10^{\circ} \mathrm{C} \mathrm{min}-1$ from 0 to $110^{\circ} \mathrm{C}$. After heating, samples were rapidly cooled in the machine and selected samples were rescanned to investigate the reversibility of thermograms. The calorimeter was calibrated using a scan rate of $10{ }^{\circ} \mathrm{C} \mathrm{min}-1$ with indium metal $(99.99 \%$ pure) for both temperature and enthalpy calibration (m.p. $=156.6^{\circ} \mathrm{C}, \Delta H=28.45 \mathrm{~J} \mathrm{~g}^{-1}$ ). A second temperature standard, $\beta$-naphthyl ethyl ether (m.p. $=35^{\circ} \mathrm{C}$ ), was used as a check of temperature calibration at lower temperatures. The accuracy of temperature and enthalpy calibration was greater than $\pm 0.5^{\circ} \mathrm{C}$. In selected experiments, samples were heated at $10^{\circ} \mathrm{C} \mathrm{min}-1$ to $60^{\circ} \mathrm{C}$ and held for various times before cooling to $20^{\circ} \mathrm{C}$ at $20^{\circ} \mathrm{C} \mathrm{min}{ }^{-1}$. These were then rescanned at $10^{\circ} \mathrm{C} \mathrm{min}{ }^{-1}$ up to a temperature of $110^{\circ} \mathrm{C}$.

(iii) Measurement of viability. Samples prepared as above were heated using the calorimeter. Pans were removed at predetermined temperatures, cooled on ice, split using a sterile scalpel and vortexmixed in $9 \mathrm{ml} \mathrm{TPB}$ for $15 \mathrm{~s}$. After resuscitation for $90 \mathrm{~min}$, survivors were counted as before.

Ribosome preparation. L. monocytogenes Scott A was grown with shaking at $30^{\circ} \mathrm{C}$ in TPB for $16 \mathrm{~h}$ to give a cell density of approximately $10^{9} \mathrm{ml}^{-1}$ The $16 \mathrm{~h}$ culture $(2 \mathrm{l})$ was centrifuged at $5000 \mathrm{~g}\left(4^{\circ} \mathrm{C}\right)$ for
$20 \mathrm{~min}$. The pellets were resuspended in $20 \mathrm{ml}$ cold ribosome buffer [10 mM-Tris/HCl, pH 7.5, $6 \mathrm{~mm}-\mathrm{MgCl}_{2}, 30 \mathrm{~mm}-\mathrm{NH}_{4} \mathrm{Cl}$ (Rheinberger et al., 1988)] and stomached for $10 \mathrm{~min}$ in reinforced plastic bags (Colworth Stomacher, Stewart Labs) to remove flagella, which were then separated from the whole cells by centrifugation for $15 \mathrm{~min}$ at $5000 \mathrm{~g}$. After discarding the supernatant, the cells were resuspended in $20 \mathrm{ml}$ cold $\left(4^{\circ} \mathrm{C}\right)$ ribosome buffer.

A French press (Aminco) was used for cell disruption. The piston/ chamber was precooled to $0{ }^{\circ} \mathrm{C}$ and washed with cold ribosome buffer before being filled with the cold $\left(4^{\circ} \mathrm{C}\right)$ cell suspension. Cell breakage was achieved by passage of the cell suspension four times using a pressure of 20000 p.s.i. (1.38 MPa). The disrupted cell suspension was collected in a chilled glass vessel and centrifuged for $30 \mathrm{~min}$ at $25000 \mathrm{~g}$ $\left(4^{\circ} \mathrm{C}\right)$. The cell debris (pellet) was discarded and the supernatant was then centrifuged at $4{ }^{\circ} \mathrm{C}$ for $2 \mathrm{~h}$ at $100000 \mathrm{~g}$ in an Europa $65 \mathrm{M}$ ultracentrifuge (MSE). The supernatant was discarded and the pellets containing the ribosomes stored at $-20^{\circ} \mathrm{C}$ for less than $28 \mathrm{~d}$.

\section{Results}

\section{Effect of $\mathrm{NaCl}$ on thermal inactivation}

A high concentration of $\mathrm{NaCl}(1.6 \mathrm{M})$ significantly increased the heat resistance of $L$. monocytogenes at temperatures between 56 and $62^{\circ} \mathrm{C}$ (Fig. 1). After $30 \mathrm{~min}$ at $56{ }^{\circ} \mathrm{C}$ in TPB (which contains $0.1 \mathrm{M}-\mathrm{NaCl}$ ), the number of surviving cells had been reduced by a factor of greater than $10^{4}$ (Fig. 1), whereas in the presence of $\mathrm{NaCl}$ (added to give a concentration of $1.6 \mathrm{M}-\mathrm{NaCl}$ in TPB), after the same time period, the number of viable cells had only been reduced by a factor of 10 . A concentration of $0.6 \mathrm{M}-\mathrm{NaCl}$ in TPB afforded a much lower level of protection. These effects have also been observed at a range of $\mathrm{pH}$ values $(4 \cdot 4-7 \cdot 0)$ (unpublished observations).

\section{DSC thermograms in the presence and absence of $\mathrm{NaCl}$}

Both strains of L. monocytogenes examined exhibited very similar patterns of endothermic transitions when scanned in the calorimeter at $10{ }^{\circ} \mathrm{C} \mathrm{min}^{-1}$. The thermogram of L. monocytogenes ATCC 19115 between 10 and $110^{\circ} \mathrm{C}$ in the absence of $\mathrm{NaCl}$ showed five distinct peaks (labelled A-E, Table 1). The first peak (A) was the largest, with a maximum at $68.6{ }^{\circ} \mathrm{C}$. Peak D $\left(92-93{ }^{\circ} \mathrm{C}\right)$ was the only peak to reappear following rapid cooling and reheating (Fig. 2). Conversely, when the sample was cooled slowly and reheated, this peak did not appear. In the presence of $0.5 \mathrm{M}-\mathrm{NaCl}$, peak $\mathrm{D}$ moved from 93.1 to $96.3^{\circ} \mathrm{C}$, whereas the major peak (A) remained at approximately $68^{\circ} \mathrm{C}$. An increase to $1.5 \mathrm{M}-\mathrm{NaCl}$ caused further movement in peak $\mathrm{D}$, this time to $103.3^{\circ} \mathrm{C}$. These results are consistent with peak $\mathrm{D}$ corresponding to DNA (Miles et al., 1986). However, at the higher $\mathrm{NaCl}$ concentration a shift was also apparent in the major peak (A) by $6{ }^{\circ} \mathrm{C}$ to $74.3{ }^{\circ} \mathrm{C}$. A general decrease in peak 

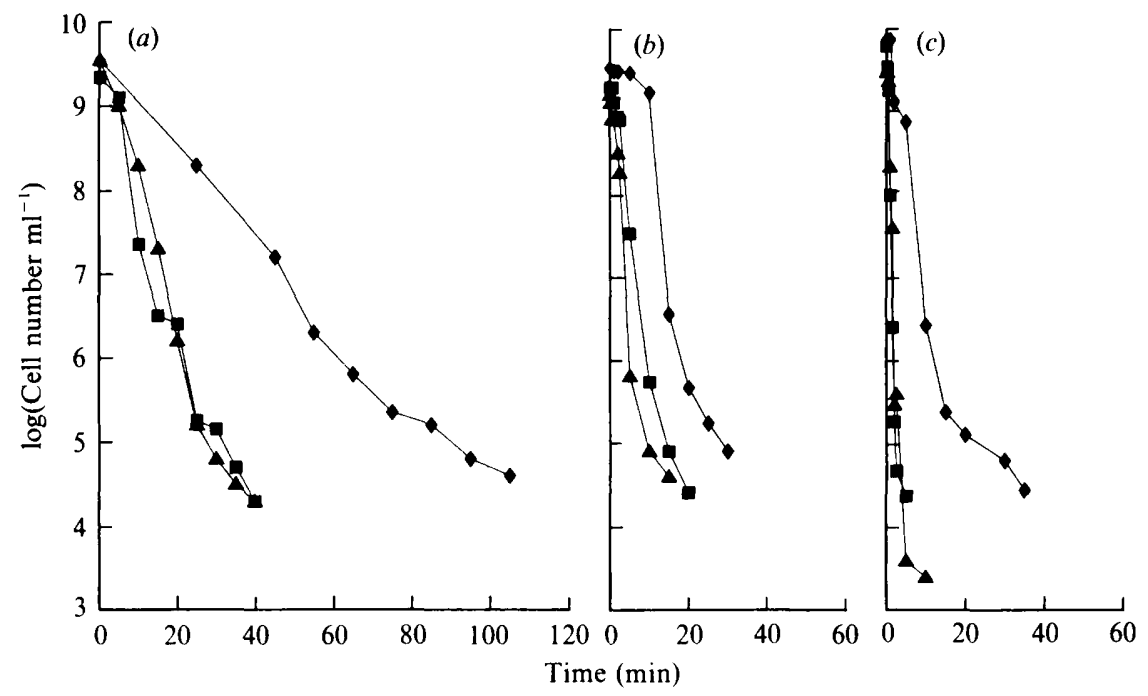

Fig. 1. Effect of $\mathrm{NaCl}$ on the thermal inactivation of L. monocytogenes ATCC 19115. Cells were heated at $(a) 56^{\circ} \mathrm{C},(b) 60^{\circ} \mathrm{C}$ and $(c) 62^{\circ} \mathrm{C}$ in TPB, pH $7 \cdot 0$, containing $0.1 \mathrm{M}-(\Delta), 0.6 \mathrm{M}-(\boldsymbol{\square})$ or $1.6 \mathrm{M}$ $(\diamond) \mathrm{NaCl}$.
Table 1. Effect of $\mathrm{NaCl}$ on the thermograms of L. monocytogenes

Cells were grown either in TPB $(0 \cdot 1 \mathrm{M}-\mathrm{NaCl})$ or in TPB with $\mathrm{NaCl}$ added to give $1.6 \mathrm{M}-\mathrm{NaCl}$ and resuspended in citrate/phosphate buffer, $\mathrm{pH} 7 \cdot 0$, containing $0,0.5 \mathrm{M}$ or $1.5 \mathrm{M}-\mathrm{NaCl}$. Values represent the mean peak positions $\left({ }^{\circ} \mathrm{C}\right)$ independently determined from two trials. The single peak obtained after a second scan is shown as $\mathrm{D}^{\prime}$.

\begin{tabular}{ccccccccc}
\hline \hline \multicolumn{2}{c}{$\begin{array}{c}\text { Concn of } \\
\text { NaCl (M) }\end{array}$} & & \multicolumn{5}{c}{ Thermogram peak positions $\left({ }^{\circ} \mathrm{C}\right)$} \\
\cline { 1 - 6 } Growth & DSC & & A & B & C & D & E & D $^{\prime}$ \\
\hline 0.1 & 0 & & 68.6 & 75.3 & 81.5 & 93.1 & 105.3 & 92.0 \\
0.1 & 0.5 & 68.4 & - & - & 96.3 & - & 95.6 \\
0.1 & 1.5 & 74.3 & - & - & 103.3 & - & 102.7 \\
1.6 & 0 & 65.4 & 76.7 & 84.5 & 94.5 & - & 92.2 \\
1.6 & 1.5 & 71.2 & - & - & 91.4 & - & - \\
\hline \hline
\end{tabular}

resolution was observed with the addition of $\mathrm{NaCl}$ (Fig. 3).

When L. monocytogenes was grown with added $\mathrm{NaCl}$ (to $1.6 \mathrm{M}$ in TPB) and resuspended in $\mathrm{NaCl}$-free buffer, the thermogram showed four peaks (A-D, Table 1). The major peak (A) had shifted to a lower temperature $\left(65.4^{\circ} \mathrm{C}\right)$ with little change in the position of the DNA peak (D). Resuspension in $1.5 \mathrm{M}-\mathrm{NaCl}$ buffer caused the major peak (A) to shift to $71.2{ }^{\circ} \mathrm{C}$. This was $3{ }^{\circ} \mathrm{C}$ lower than the position observed with bacteria grown in TPB without additional $\mathrm{NaCl}$ and subjected to identical resuspension conditions. The DNA peak (D) also shifted by $3{ }^{\circ} \mathrm{C}$ to a lower temperature of $91.4{ }^{\circ} \mathrm{C}$ (Table 1 ).

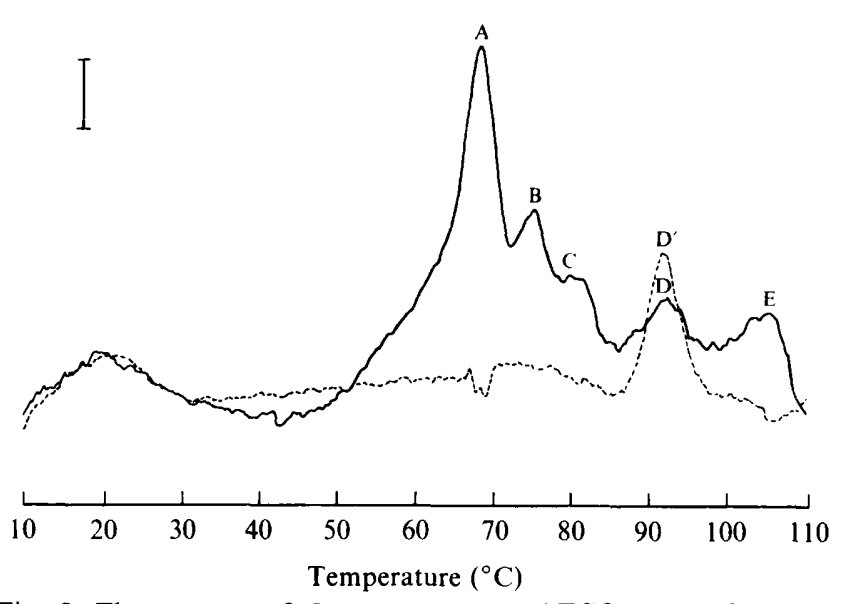

Fig. 2. Thermogram of L. monocytogenes ATCC 19115. Samples (approx. $11 \mathrm{mg}$ wet wt) were heated at $10^{\circ} \mathrm{C} \min 1$ from $0{ }^{\circ} \mathrm{C}$ to $110^{\circ} \mathrm{C}$ (-). After heating the sample was cooled to its starting temperature and reheated as before (--). Letters indicate the major peaks as described in Table 1. Bar, $30 \mathrm{~J} \mathrm{~kg}^{-1}{ }^{\circ} \mathrm{C}^{-1}$.

Effect of $\mathrm{NaCl}$ on the viability of L. monocytogenes during heating in the calorimeter.

Viability of cells heated in the calorimeter in the absence of added $\mathrm{NaCl}$ showed a sudden and rapid decrease over the range 60 to $70^{\circ} \mathrm{C}$ (Fig. $4 a$ ). This reduction coincided with the endothermic reaction which resulted in the major peak (A) of the DSC thermogram. No viable cells were detected at temperatures above $80^{\circ} \mathrm{C}$, which is lower than the DNA melting temperature $\left(93^{\circ} \mathrm{C}\right)$. Viability of cells heated in the calorimeter in the presence of $1.5 \mathrm{M}-\mathrm{NaCl}$ showed similar death kinetics to 


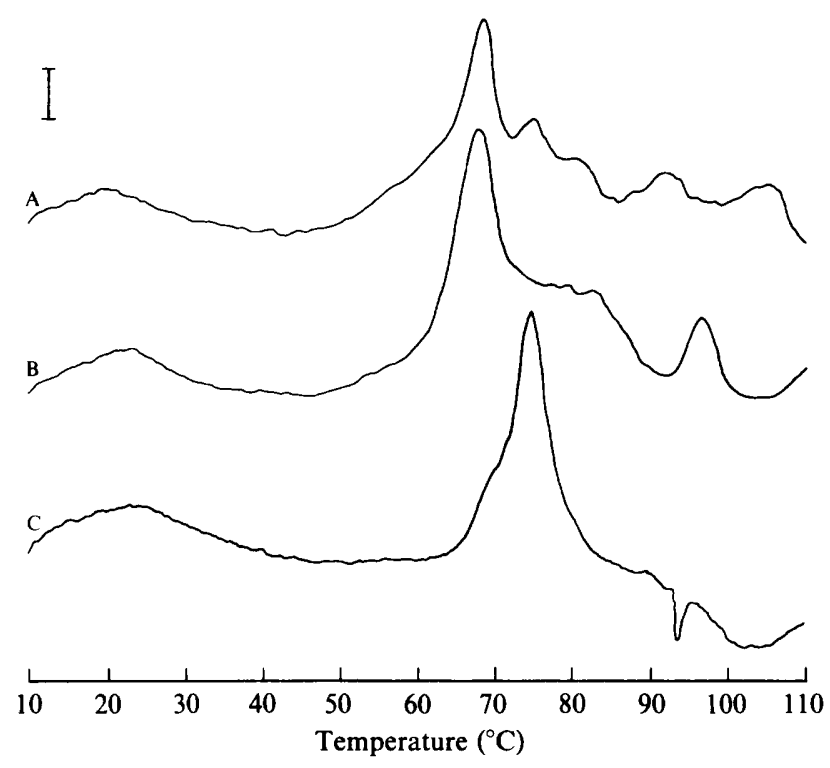

Fig. 3. Effect of $\mathrm{NaCl}$ on the thermogram of $L$. monocytogenes ATCC 19115. Vegetative cells were resuspended in citrate/phosphate buffer, pH 7.0, containing no $\mathrm{NaCl}$ (A), $0.5 \mathrm{M}-$ (B) or $1.5 \mathrm{M}-$ (C) $\mathrm{NaCl}$. Bar, $30 \mathrm{~J} \mathrm{~kg}^{-1}{ }^{\circ} \mathrm{C}^{-1}$.

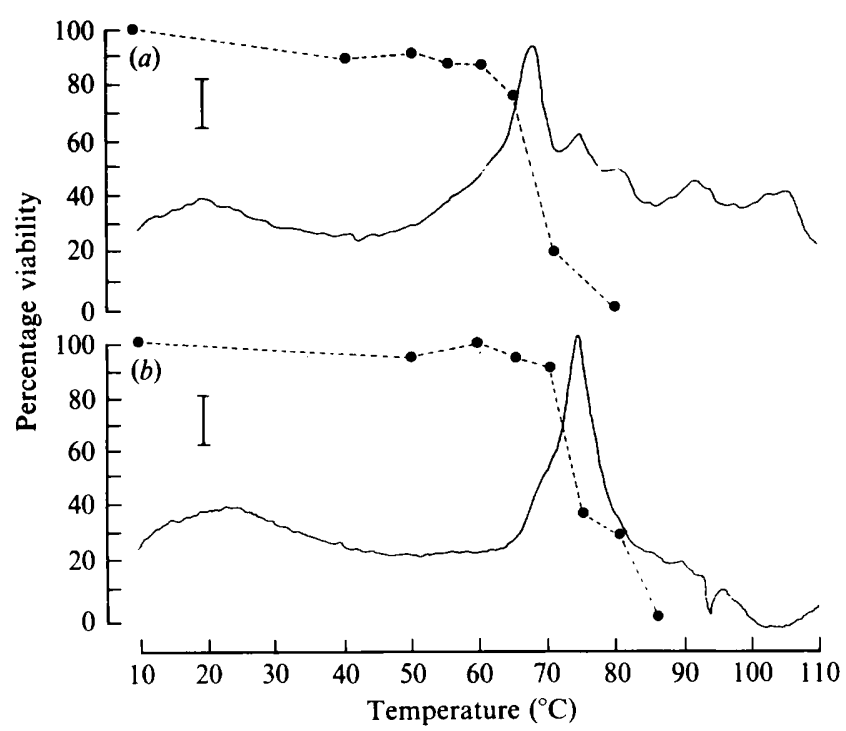

Fig. 4. Viability of L. monocytogenes ATCC 19115 in the presence of 0 and $1.5 \mathrm{M}-\mathrm{NaCl}$. Cells were grown in TPB and resuspended in citrate/ phosphate buffer, $\mathrm{pH} 7.0$, containing $(a)$ no $\mathrm{NaCl}$ or $(b) 1.5 \mathrm{M}-\mathrm{NaCl}$. The thermogram (-) was determined as in Fig. 2. Viability (---) was determined from cell suspensions heated in aluminium pans in the calorimeter. Bar, $30 \mathrm{~J} \mathrm{~kg}^{-1}{ }^{\circ} \mathrm{C}^{-1}$.

those heated in the absence of salt. However, here the reduction in viable-cell numbers occurred over the range 70 to $80^{\circ} \mathrm{C}$. This increase in heat resistance corresponded to the $6{ }^{\circ} \mathrm{C}$ shift in the major peak (A) in response to heating in $1.5 \mathrm{M}-\mathrm{NaCl}$ (Fig. $4 b$ ).

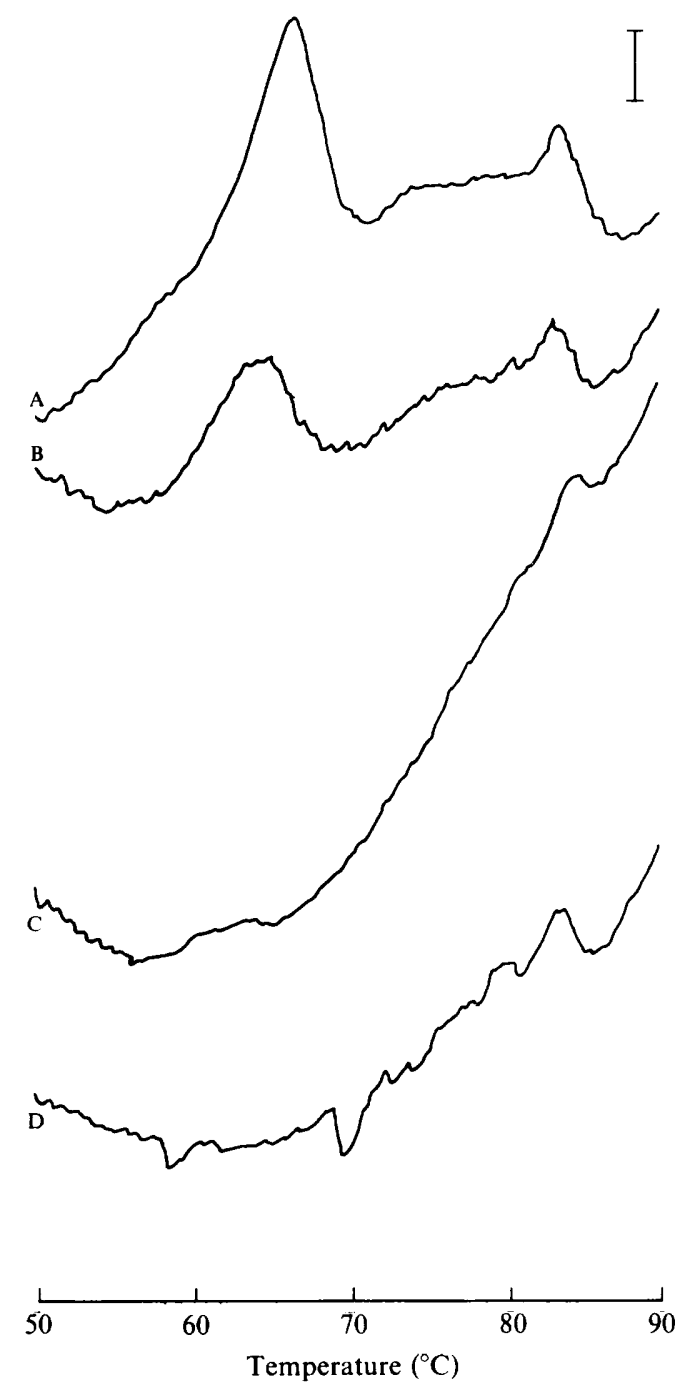

Fig. 5. Effect of holding time at $60^{\circ} \mathrm{C}$ on the thermogram of $L$. monocytogenes Scott $\mathrm{A}$. Cells, in buffer without added $\mathrm{NaCl}$, were heated in the calorimeter pans to $60^{\circ} \mathrm{C}$ and held for $0 \mathrm{~min}$ (B), $2 \mathrm{~min}$ (C) and $5 \mathrm{~min}$ (D). These were then cooled to $20^{\circ} \mathrm{C}$ at $20^{\circ} \mathrm{C} \mathrm{min}^{-1}$ followed by reheating to $110^{\circ} \mathrm{C}$ at $10^{\circ} \mathrm{C} \mathrm{min}-1$. These are compared to a control thermogram (A) for a cell suspension heated from 0 to $110^{\circ} \mathrm{C}$ without any intermediate cooling and reheating. Bar, $30 \mathrm{~J} \mathrm{~kg}^{-1}{ }^{\circ} \mathrm{C}^{-1}$.

Changes in thermogram peak height and position in response to holding at $60^{\circ} \mathrm{C}$

In view of the good correlation between loss of viability and peak A (Fig. 4), it seemed pertinent to examine the time course of peak loss during heating in the calorimeter. Heating cells in buffer without added $\mathrm{NaCl}$ to $60{ }^{\circ} \mathrm{C}$, with no holding time, caused this peak to broaden and decrease in height from approximately 180 to $60 \mathrm{~J} \mathrm{~kg}^{-1}{ }^{\circ} \mathrm{C}^{-1}$ (Fig. 5, A and B). Holding at $60^{\circ} \mathrm{C}$ for 2 min resulted in a further reduction in major peak height to $<30 \mathrm{~J} \mathrm{~kg}^{-1}{ }^{\circ} \mathrm{C}^{-1}$ (Fig. 5, C) and holding at $60{ }^{\circ} \mathrm{C}$ for $5 \mathrm{~min}$ culminated in its disappearance (Fig. 5 , 


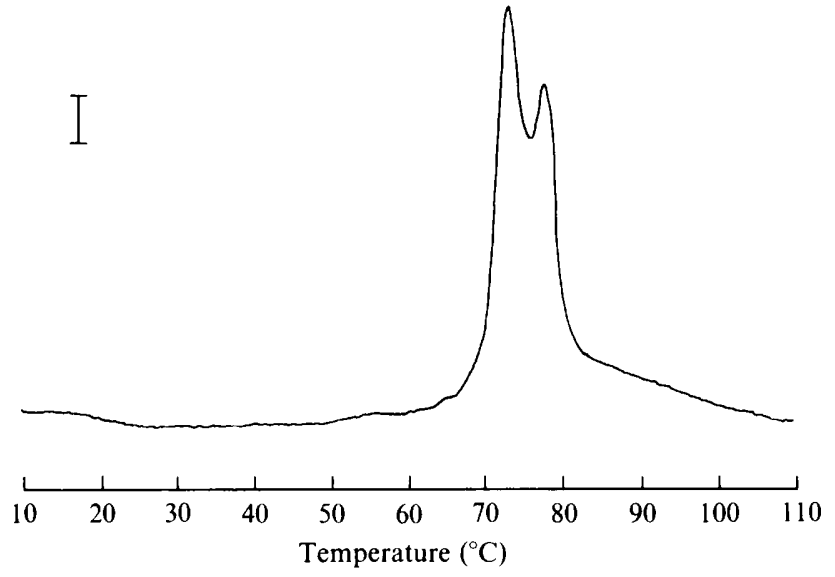

Fig. 6. Thermogram of a ribosomal fraction. A sample (10.8 mg wet wt) in $\mathrm{Tris} / \mathrm{HCl} / \mathrm{MgCl}_{2} / \mathrm{NH}_{4} \mathrm{Cl}$ buffer, $\mathrm{pH} 7.5$, was heated at $10^{\circ} \mathrm{C} \mathrm{min}{ }^{-1}$ from 0 to $110^{\circ} \mathrm{C}$ in the calorimeter. Bar, $30 \mathrm{~J} \mathrm{~kg}^{-1}{ }^{\circ} \mathrm{C}^{-1}$.

D). Holding for 2 and $5 \mathrm{~min}$ at $60{ }^{\circ} \mathrm{C}$ would have reduced viability by about 90 and $99.5 \%$, respectively (Fig. 1 b). The DNA melting endotherm (peak D) was largely unaffected by holding times up to $5 \mathrm{~min}$ at $60^{\circ} \mathrm{C}$ and was visible on all thermograms.

\section{Thermogram of a ribosome-enriched cytoplasmic fraction}

A ribosome-containing cell fraction resuspended in Tris $/ \mathrm{HCl} / \mathrm{MgCl}_{2} / \mathrm{NH}_{4} \mathrm{Cl}$ buffer (Rheinberger et al., 1988) gave a double peak between 68 and $82^{\circ} \mathrm{C}$ when heated in the calorimeter at $10{ }^{\circ} \mathrm{C} \mathrm{min}-1$. The position of the major peak is comparable to that of whole cells when resuspended in $1.5 \mathrm{M}-\mathrm{NaCl}$.

\section{Discussion}

The effects of the environment in modulating the response of bacteria to stress have been frequently described in general terms, but the underlying molecular mechanisms are poorly understood. DSC allows whole cells to be studied whilst applying a heat stress. Thermograms of several bacterial species have been published (Verrips \& K wast, 1977; Miles et al., 1986) and in general the scans of $L$. monocytogenes resemble other mesophilic bacteria with respect to the number and position of the major peaks.

DSC scans of whole cells show only a few peaks but these can be due to a larger number of transitions which are not resolved from each other. The peaks in the region of the thermogram at which loss of viability was observed are irreversible and most probably due to protein unfolding and denaturation. Contributions from other macromolecules cannot be ruled out but the irreversible component of DNA and RNA melting has been considered to be only a minor fraction of total enthalpy (Lepock et al., 1988). Peak area is a function of protein concentration and the specific calorimetric enthalpy of the protein (Privalov \& Knechninashvili, 1974). Hence, large peaks in thermograms of whole cells will either be due to proteins present at high concentrations or, more probably, to combinations of several proteins with peaks at the same transition temperature. The disadvantage of being unable to resolve contributions from individual proteins is offset by the reproducibility of the method and the very significant gain of the ability to investigate changes in whole-cells concurrently with measuring viability.

The temperature tolerance of $L$. monocytogenes was increased by the addition of $\mathrm{NaCl}$ to cell suspensions and, at the same time, the major thermogram peaks were shifted to a higher temperature. A similar change has been observed in mammalian cells subjected to heat shocks where glycerol protects the cells from hyperthermia and causes an upward shift in both the temperature at which denaturation occurs and the major thermogram peaks (Lepock et al., 1988). In L. monocytogenes, loss of viability of cells heated in the calorimeter was correlated with the first major peak which was at $68^{\circ} \mathrm{C}$ in low-salt $(0.1 \mathrm{M})$ and at $74^{\circ} \mathrm{C}$ in high-salt $(1.6 \mathrm{M})$ solutions. A shift of about $5^{\circ} \mathrm{C}$ in the major DSC peak was observed in Citrobacter freundii when resuspended in $1.5 \mathrm{M}$-sucrose, but, in contrast to $L$. monocytogenes, not with salt (Verrips \& Kwast, 1977). Addition of $\mathrm{NaCl}$ will, in the short term, cause water loss from the cells by osmosis and a consequent increase in internal solute concentration. Cells with dehydrated cytoplasm such as Bacillus endospores have well-known heat resistance but, in addition, thermal protection of a variety of cytoplasmic enzymes by $\mathrm{NaCl}$ or other ions has been shown for vegetative cells of Bacillus coagulans (Crabb et al., 1975; Jones \& Spencer, 1985) and ionic protection has been proposed as the thermal-tolerance mechanism employed by facultative thermophilic bacteria (Amelunxen \& Murdock, 1978). When L. monocytogenes was grown in media containing high levels of $\mathrm{NaCl}$, osmotic adaptation occurred and thermogram peak $\mathrm{A}$ was shifted from $68.6^{\circ} \mathrm{C}$ to only $71.2{ }^{\circ} \mathrm{C}$, compared with $74.3^{\circ} \mathrm{C}$ when cells were first resuspended in high-salt solution (Table 1). Resuspension of cells grown in high-salt medium in $\mathrm{NaCl}$-free buffer reduced the thermogram peak $\mathrm{A}$ transition temperature to $65.4{ }^{\circ} \mathrm{C}$, which is $3{ }^{\circ} \mathrm{C}$ below that in 'normal cells'. These results indicate that the thermogram peaks respond rapidly and in a predictable way to the internal osmotic status of the cell. We would also suggest that the internal solute composition and concentration, and/or water content, are major factors in the thermal tolerance of Listeria and other mesophilic bacteria. 
Heating bacteria at $60^{\circ} \mathrm{C}$ in the calorimeter for different times indicated that the time course for denaturation of peak A closely followed the death kinetics. It will be of considerable interest, therefore, to try to identify the major cellular components which contribute to this first peak. Ribosomes, which contain approx. $38 \%$ protein (Noller \& Nomura, 1987), comprise a major part of the dry weight of the bacterial cell. Since there is some evidence that mild heat stress can damage ribosomes directly (Hurst, 1984) or indirectly through magnesium loss (Hurst \& Hughes, 1978), ribosomes have been proposed as possible contributors to the major DSC peak (Verrips \& Kwast, 1977; Miles et al., 1986). A ribosomal fraction from $L$. monocytogenes has a DSC thermogram with a single or double peak between 64 and $70{ }^{\circ} \mathrm{C}$. The exact position and shape of the peak is dependent upon the ionic composition and concentration of the suspension buffer used. Under ionic conditions which stabilize the ribosome (Rheinberger et al., 1988), the peaks observed in the thermogram of the ribosome cell fraction (Fig. 6) correspond to the major peak in whole cells resuspended in high ionic strength medium and thermally most resistant (Fig. 4). Further work is in progress to elucidate the exact relationship between ionic environment, ribosomal stability and thermal resistance of Listeria.

The authors wish to thank Grahame Gould and Peter Wilding for their helpful discussions and support during the course of this work. Peter Newham is thanked for his invaluable technical assistance in the preparation of ribosomes.

\section{References}

Amelunxen, R. E. \& Murdock, A. L. (1978). Mechanisms of thermophily. CRC Critical Reviews in Microbiology 6, 343-393.

Bunning, V. K., Donnelly, C. W., Peeler, J. T., Briggs, E. H., Bradshaw, J. G., Crawford, R. G., Beliveau, C. M. \& Tierney, J. T. (1988). Thermal inactivation of Listeria monocytogenes within bovine milk phagocytes. Applied and Environmental Microbiology 54, 364-370.

COLE, M. B. \& Jones, M. V. (1990). A submerged-coil heating apparatus for investigating the thermal inactivation of bacteria. Letters in Applied Microbiology 11, 233-235.

CONNOR, D. E., BRACKeTt, R. E. \& BEUCHAT, L. R. (1986). Effect of temperature, $\mathrm{NaCl}$ and $\mathrm{pH}$ on growth of Listeria monocytogenes in cabbage juice. Applied and Environmental Microbiology 52, 59-63.

CoOTE, P. J., Holyoak, C. D. \& Cole, M. B. (1991). Thermal inactivation of Listeria monocytogenes during simulated microwave heating. Journal of Applied Bacteriology (in the Press).

CORRY, J. E. L. (1974). Effects of sugars and polyols on the heat resistance of salmonellae. Journal of Applied Bacteriology 37, 31-43.

Crabe, J. W., Murdock, A. L. \& AmelunXen, R. E. (1975). A proposed mechanism of thermophily in facultative thermophiles. Biochemical and Biophysical Research Communications 62, 627-633.
Gaze, J. E., Brown, G. D., Gaskell, D. E. \& Banks, J. G. (1989) Heat resistance of Listeria monocytogenes in homogenates of chicken, beef steak and carrot. Food Microbiology 6, 251-259.

GOEPFERT, J. M., ISKANDER, I. K. \& AMUNDSON, C. H. (1970). Relation of the heat resistance of Salmonellae to the $a_{\mathrm{w}}$ of the environment. Applied Microbiology 19, 429-433.

Grieme, L. E. \& Barbano, D. M. (1983). Method for use of a differential scanning calorimeter for determination of bacterial thermal death times. Journal of Food Protection 46, 797-801.

Hurst, A. (1984). Reversible heat damage. In Repairable Lesions in Microorganisms, pp. 303-318. Edited by A. Hurst \& A. Nasim. London: Academic Press.

HURST, A. \& HUGHES, A. (1978). Stability of ribosomes of Staphylococcus aureus $\mathbf{S 6}$ sublethally heated in different buffers. Journal of Bacteriology 133, 564-568.

HURST, A. \& Hughes, A. (1981). Repair of salt tolerance and recovery of lost D-alanine and magnesium following sublethal heating of Staphylococcus aureus are independant events. Canadian Journal of Microbiology 27, 627-632.

JONES, M. V. \& SPENCER W. N. (1985). Thermostability of the enzymes of the tricarboxylic acid cycle of Bacillus coagulans. Antonie van Leeuwenhoek 51, 193-201.

Lambert, P. A. \& Hammond, S. M. (1973). Potassium fluxes, first indication of membrane damage in microorganisms. Biochemical and Biophysical Research Communications 54, 796-799.

LEE, A. C. \& GoEPFERT, J. M. (1975). Influence of selected solutes on thermally induced death and injury of Salmonella typhimurium. Journal of Milk and Food Technology 38, 175-200.

LEPOCK, J. R., FreY, H. E., RodAHL, M. \& KRUUV, J. (1988). Thermal analysis of CHL V79 cells using differential scanning calorimetry: implications for hyperthermic cell killing and heat shock response. Journal of Cellular Physiology 137, 14-24.

Mackey, B. M., Parsons, S. E., Miles, C. A. \& OWen, R. J. (1988). The relationship between base composition of bacterial DNA and its intracellular melting temperature as determined by differential scanning calorimetry. Journal of General Microbiology 134, 11851195.

McCoy, D. R. \& ORdal, Z. J. (1979). Thermal stress of Pseudomonas fluorescens in complex media. Applied and Environmental Microbiology 37, 443-448.

McDonough, F. E. \& HaRgrove, R. E. (1968). Heat resistance of Salmonella in dried milk. Journal of Dairy Science 51, 1587-1591.

Miles, C. A., Mackey, B. M. \& Parsons, S. E. (1986). Differential scanning calorimetry of bacteria. Journal of General Microbiology 132, 939-952.

Noller, H. F. \& Nomura, M. (1987). Ribosomes. In Escherichia coli and Salmonella typhimurium : Cellular and Molecular Biology, pp. 104125. Edited by F. C. Neidhardt, J. L. Ingraham, K. B. Low, B. Magasanik, M. Schaechter \& H. E. Umbarger. Washington, DC: American Society for Microbiology.

Privalov, P. L. \& Knechninashvili, N. N. (1974). A thermodynamic approach to the stabilization of globular protein structure: a calorimetric study. Journal of Molecular Biology 86, 665-654.

RAY, B. (1984). Reversible freeze injury. In Repairable Lesions in Microorganisms, pp. 237-271. Edited by A. Hurst \& A. Nasim. London: Academic Press.

RAY, B. (1986). Impact of bacterial injury and repair in food microbiology: its past, present and future. Journal of Food Protection 49, 651-655.

Rheinberger, H., Geigenmuller, U., Wedde, M. \& Neirhaus, K. H. (1988). Parameters for preparation of E. coli ribosomes and ribosomal sub-units active in tRNA binding. Methods in Enzymology $164,658-662$.

VERRIPS, C. T. \& KWAST, R. H. (1977). Heat resistance of Citrobacter freundii in media with various water activities. European Journal of Applied Microbiology 4, 225-231. 